\title{
Long-term Declines in the Size of Northern Fulmar (Fulmarus glacialis) Colonies on Eastern Baffin Island, Canada
}

\author{
Mark L. Mallory, ${ }^{1,2}$ Cody J. Dey, ${ }^{3,4}$ Jessie McIntyre, ${ }^{1}$ Isabeau Pratte, ${ }^{1}$ Carolyn L. Mallory, ${ }^{1}$ Charles M. Francis, ${ }^{5}$ \\ Amie L. Black, ${ }^{6}$ Catherine Geoffroy, ${ }^{1}$ Rian Dickson, ${ }^{7}$ and Jennifer F. Provencher ${ }^{1,3}$
}

(Received 5 October 2019; accepted in revised form 18 March 2020)

\begin{abstract}
We censused three colonies of Northern Fulmars (Fulmarus glacialis) along eastern Baffin Island, Canada, that were estimated to support 155000 breeding pairs in 1973, but had not been adequately counted since then. The colonies were surveyed in July and August 2018 using photographs taken from a helicopter or a drone. The combined estimated colony sizes were 36500 pairs, much smaller than historical estimates. Although the 1973 estimates were coarse, this difference represents an apparent $3+\%$ annual decline in numbers at each colony over approximately four decades or more than $87 \%$ over three generations (66 years). Several factors may be contributing to these declines, including changes in winter food supplies and the susceptibility of fulmars to fisheries bycatch. We recommend efforts to survey the remaining major fulmar colonies in Arctic Canada to assess the overall population size and trends, and allow for further analyses of potential population drivers.
\end{abstract}

Key words: seabird; monitoring; populations; Arctic

RÉSUMÉ. Nous avons recensé trois colonies de fulmars boréaux (Fulmarus glacialis) sur la côte est de l'île de Baffin, au Canada. Selon des estimations réalisées en 1973, 155000 couples reproducteurs y nichaient, mais aucun dénombrement adéquat n'avait été effectué depuis. Les colonies ont été recensées en juillet et en août 2018 au moyen de photographies prises à partir d'un hélicoptère ou d'un drone. La taille combinée des colonies a été estimée à 36500 couples, soit un nombre beaucoup moins élevé que les estimations précédentes. Bien que les estimations de 1973 étaient des estimations grossières, cette différence représente une baisse annuelle apparente de plus de $3 \%$ à chacune des colonies sur environ quatre décennies, soit plus de $87 \%$ sur trois générations (66 ans). Ces diminutions peuvent être attribuables à plusieurs facteurs, dont les changements caractérisant les approvisionnements en nourriture pendant l'hiver et la susceptibilité des fulmars à faire l'objet de captures accessoires. Nous recommandons que des efforts soient faits pour recenser les grandes colonies de fulmars qui restent dans l'Arctique canadien afin d'évaluer la taille globale de la population et les tendances la caractérisant, ainsi que pour pousser plus loin l'analyse des facteurs susceptibles d'avoir un effet sur leurs populations.

Mots clés : oiseau de mer; surveillance; populations; Arctique

Traduit pour la revue Arctic par Nicole Giguère.

\footnotetext{
${ }^{1}$ Department of Biology, Acadia University, 33 Westwood Avenue, Wolfville, Nova Scotia B4P 2R6, Canada

${ }^{2}$ Corresponding author: mark.mallory@acadiau.ca

${ }^{3}$ Environment and Climate Change Canada, Canadian Wildlife Service, 351 St. Joseph Boulevard, Gatineau, Quebec K1A 0H3, Canada

${ }^{4}$ Great Lakes Institute for Environmental Research, University of Windsor, 401 Sunset Drive, Windsor, Ontario N9B 3P4, Canada

${ }^{5}$ Environment and Climate Change Canada, Canadian Wildlife Service, National Wildlife Research Centre, Raven Road, Carleton University, Ottawa, Ontario K1A 0H3, Canada

${ }^{6}$ Environment and Climate Change Canada, Wildlife and Landscape Science Directorate, National Wildlife Research Centre, Raven Road, Carleton University, Ottawa, Ontario K1A 0H3, Canada

${ }^{7}$ Black Duck Biological, 1965 Price Road, Gabriola, British Columbia V0R 1X7, Canada

(C) The Arctic Institute of North America
} 


\section{INTRODUCTION}

The Canadian Arctic supports millions of breeding seabirds annually (Gaston et al., 2012); most birds are found principally near a few, typically large colonies during the summer months (Mallory et al., 2019). As upper trophic level predators, seabirds are an important component of Arctic marine ecosystems and have been used as key biomonitors of the health of the Arctic marine environment (Gaston et al., 2005; Mallory and Braune, 2012). Seabirds respond to environmental changes in marine food supplies induced by changing climate and anthropogenic activities, thus they also serve as important bioindicators of changes underway in food chains of marine waters (Frederiksen et al., 2007; Piatt et al., 2007; Sydeman et al., 2017).

Assessing responses of seabird populations to environmental stressors typically requires that we determine changes in breeding numbers (Gaston et al., 2009; Paleczny et al., 2015). However, counting the numbers of Arctic-nesting seabirds in Canada has been challenging (Gaston et al., 2012), primarily because of the remote locations, limited infrastructure, and inherent high costs of accessing sites (Mallory et al., 2018). As a consequence of logistic and financial challenges, longterm monitoring of established research plots has been undertaken at a limited number of colonies of selected species (Gaston, 2003; Gaston et al., 2005) and has been combined with intermittent full colony censuses to track population trends (Gaston et al., 2006). The result is that some large colonies have only been counted once or twice, which precludes any reliable assessment of trends.

The Northern Fulmar (Fulmarus glacialis) breeds in large colonies around the North Atlantic and North Pacific Oceans into Arctic waters, but its global population status is poorly known (Mallory et al., 2012). The IUCN Red List suggests that the global population is increasing, but the population in Europe, representing about half the global population, was estimated to have declined more than $40 \%$ since the mid-1980s (BirdLife International, 2019). In Arctic Canada, 11 colonies are located around the coasts of Baffin Bay, Lancaster, and Jones sounds (Fig 1; Wong et al., 2018). These colonies support an estimated 174000 breeding pairs based on census data available up to 2012, although estimated numbers were higher in earlier decades (Gaston et al., 2012). Of this total, five colonies on eastern Baffin Island were estimated to support $60 \%$ of the breeding pairs, but the data on which those estimates are based are dated (Gaston et al., 2012). Moreover, published colony sizes were derived from varied methodologies (expert opinion estimates during aerial surveys, counts from colony photos taken before 1990, counts and photos covering only part of the colony; see Hatch and Nettleship, 1998; Mallory and Gaston, 2005; Gaston et al., 2006).

The population estimates for Northern Fulmars in Arctic Canada require urgent updating, in particular because concerns have been expressed recently about possible negative impacts on these colonies with the development and expansion of Arctic fisheries in the region since the 1990s and the high susceptibility of fulmars to incidental bycatch in fishing gear (Hedd et al., 2016; Anderson et al., 2018). To address this information gap, we censused three of the major Northern Fulmar colonies on Baffin Island in 2018 using digital photography. Based on anecdotal reports from communities and researchers and the overall trends in Canadian Northern Fulmar populations (Gaston et al., 2006, 2012), we anticipated that colony sizes would be smaller than estimated previously, but the magnitude of the decline was unknown.

\section{METHODS}

We conducted a photo census of three Northern Fulmar colonies (Fig. 1) at Buchan Gulf $\left(71.83^{\circ} \mathrm{N}, 74.5^{\circ} \mathrm{W}\right.$; south of the community of Pond Inlet/Mittimatalik), Scott Inlet $\left(71.05^{\circ} \mathrm{N}, 71.13^{\circ} \mathrm{W}\right.$, north of Clyde River/ Kannigiqtugaapik), and Qaqulluit National Wildlife Area $\left(67.23^{\circ} \mathrm{N}, 62.47^{\circ} \mathrm{W}\right.$; Cape Searle, south of Qikiqtarjuaq). Birds from these colonies may be at high risk to fisheries bycatch in Baffin Bay, and colony census information is decades out-of-date (Anderson et al., 2018). It was possible for us to photograph the two northern colonies from a helicopter, but for logistic reasons the southern colony was photographed using an unmanned aerial vehicle (drone) later in the season working with the local community. Northern Fulmars come in two main colour morphs: a very light, largely white morph (LL), and a darker, highly variable gray morph (L, D, or DD; Mallory et al., 2012). Buchan Gulf and Scott Inlet colonies are dominated by very light fulmars (as opposed to the predominantly gray fulmars at most other Nunavut colonies; Mallory et al., 2012), which makes them relatively easy to spot against gray cliffs (Fig. 2). The Qaqulluit colony is largely gray morphs, which are easy to spot against the green, vegetated tops of the rock stacks, but more difficult to see in shaded areas of cliffs (Figs. 2, 3).

On 7 July 2018, we surveyed the Buchan Gulf and Scott Inlet colonies using a helicopter based out of Pond Inlet. Weather conditions were suitable, with winds from the northeast at less than $16 \mathrm{~km} / \mathrm{h}$, mostly sunny, and with horizontal visibility effectively unlimited. Surveys were conducted between 1030 and 1330 hours. The helicopter flew first to Buchan Gulf, where it moved to within $300 \mathrm{~m}$ of the cliffs (the recommended distance for aerial access of Arctic seabird colonies; Environment Canada, 2005) and then flew along the nesting cliff faces at $\sim 30 \mathrm{~km} / \mathrm{h}$ and an altitude of $\sim 250 \mathrm{~m}$ while the observer took overlapping photographs of the entire cliff face with a Canon EOS 5D digital camera (12 megapixel) using a $100 \mathrm{~mm}$ lens. The second observer watched for concentrations of birds or birds moving off the cliffs (in which case the helicopter would move farther away to minimize disturbance; however, these movements did not occur). Photos of the colony taken from 


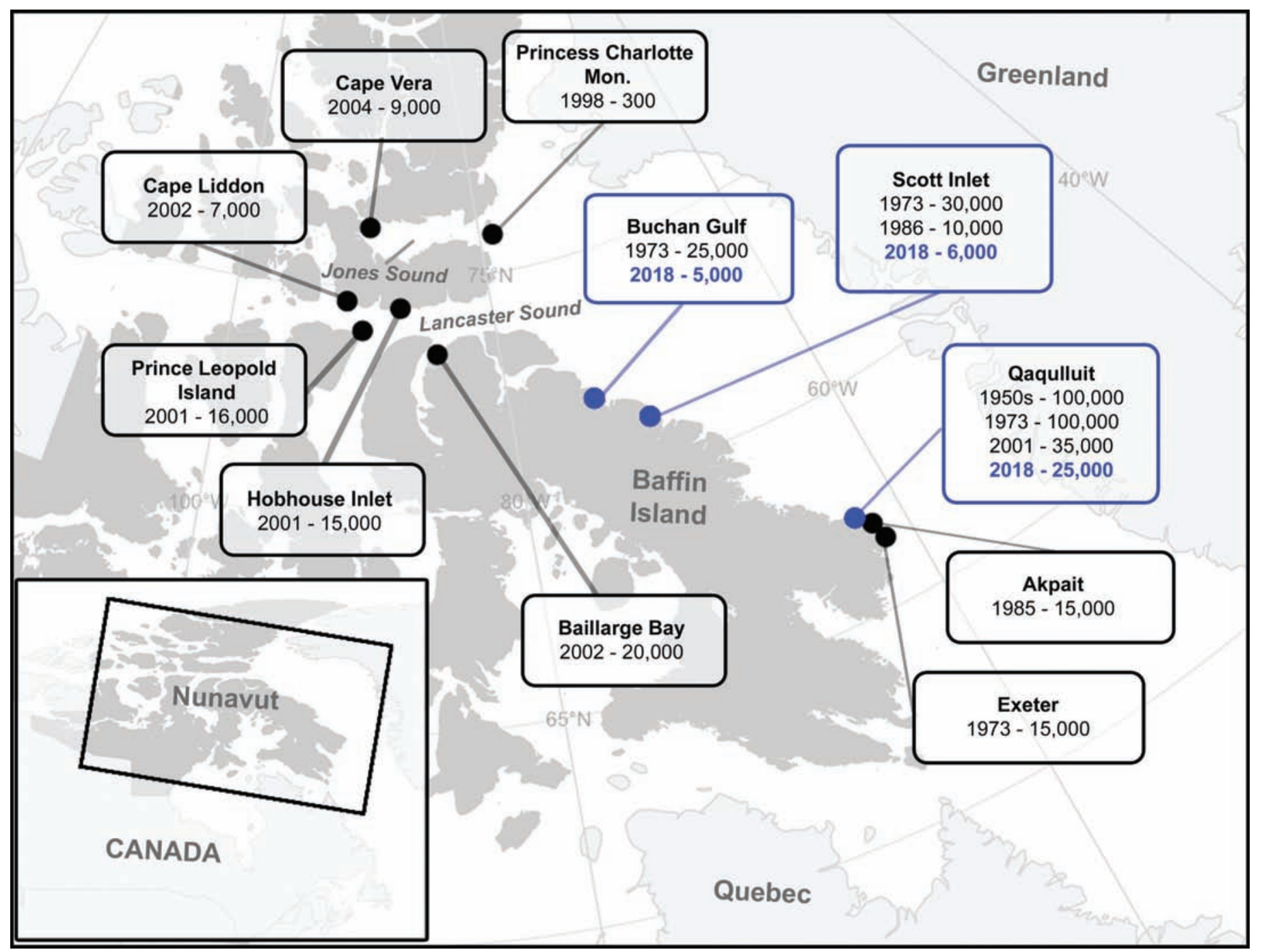

FIG. 1. Northern Fulmar (Fulmarus glacialis) breeding colonies in Canada. The last year surveyed with the population estimates (breeding pairs) are shown for all colonies (Gaston et al., 2006, 2012). Colonies with updated estimates in 2018 are shown in blue, and boxes include all available colony census estimates and year of census.

the air in earlier years were used to ensure the full extent of the colonies was photographed. Following completion of photographs of the Buchan Gulf colony ( $13 \mathrm{~min})$, the helicopter departed for Clyde River to refuel, and then continued on to nearby Scott Inlet. Once there, a similar procedure was undertaken. Scott Inlet was photographed in $\sim 6 \mathrm{~min}$, after which the helicopter returned to Pond Inlet.

The second survey was undertaken at Qaqulluit on 11 August 2018 by a boat-based research team, using a DJI Phantom 4 Pro drone with a $35 \mathrm{~mm}, 20$-megapixel camera to take photographs. Conditions were clear, with unlimited visibility, and winds from the northeast at less than $23 \mathrm{~km} / \mathrm{h}$. We piloted the drone from a peninsula within $\sim 1 \mathrm{~km}$ of the colony. The drone ascended to an altitude of approximately $600 \mathrm{~m}$ above sea level and then made passes over the $440 \mathrm{~m}$ tall rock towers at the Cape, taking photographs from a distance of $\sim 150 \mathrm{~m}$. Given time limitations, we focused on censusing the top surfaces of the rock towers where most birds nest (Mallory and Gaston, 2005) and which had not been observed for several decades
(Gaston et al., 2006). Although we took photographs of much of the cliff faces along the rock towers from the water below, those images did not include the entire colony. The angle of the image taken from below the cliffs meant that counts could substantially underestimate birds for some areas (e.g., in some cases no fulmars could be observed on what were obviously grassy ledges; such sites could potentially support hundreds of nests; Gaston et al., 2006). Furthermore, most images had areas with poor resolution or dark shading where birds could be nesting. However, M. Mallory conducted a census of this colony in 2001, principally the cliff faces, and thus we used estimates of fulmars nesting on the cliffs from the 2001 survey (making our 2018 survey an incomplete survey of this colony).

Following image acquisition in the field, all digital photographs were archived with the Canadian Wildlife Service. Copies were sent to Acadia University, where they were stitched together using Microsoft Powerpoint or Adobe Photoshop into larger images that encompassed contiguous portions of the cliffs (to ensure no duplication of 

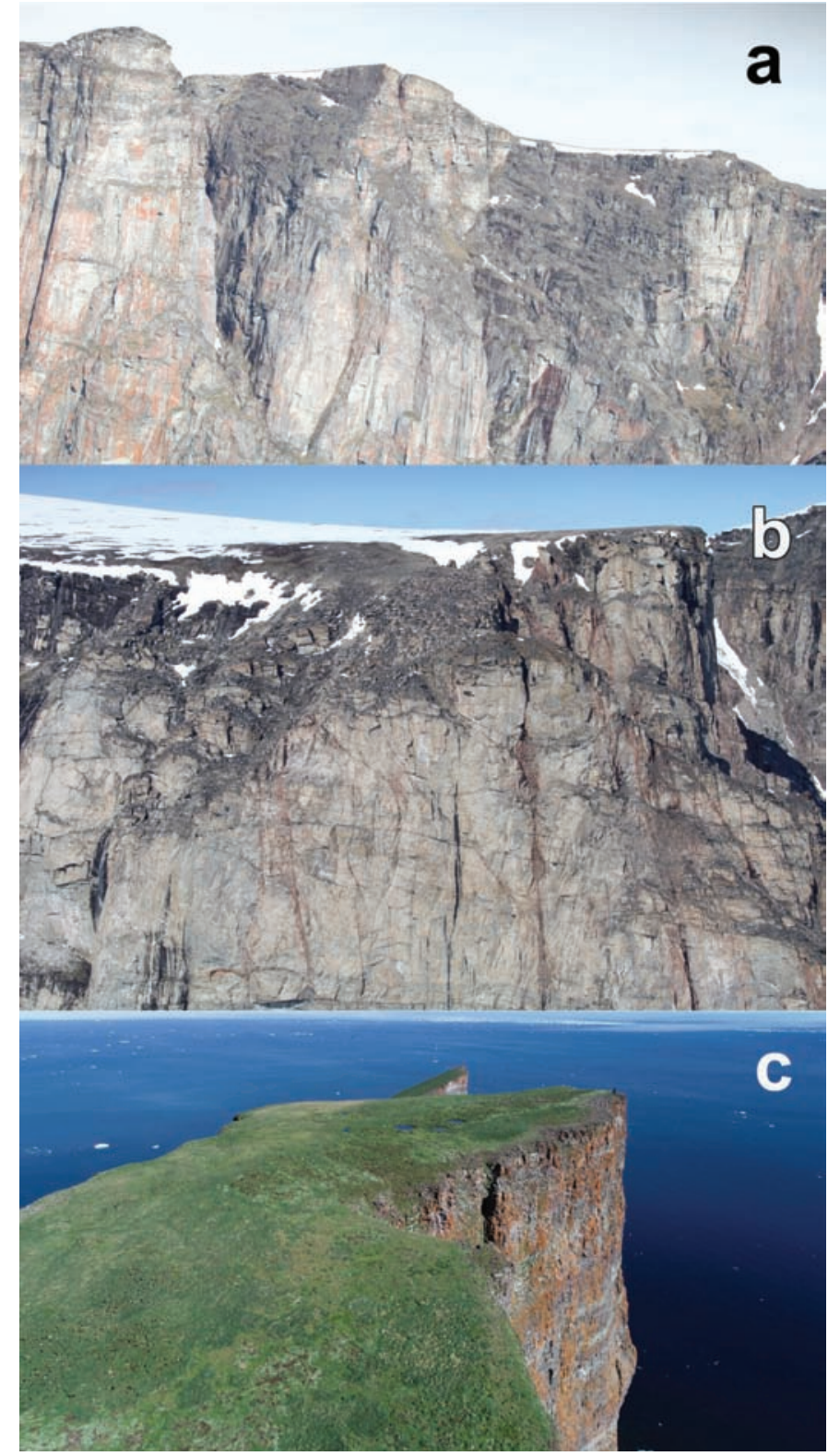

FIG. 2. Representative photos from the Northern Fulmar colonies on eastern Baffin Island, Canada: a) Buchan Gulf, b) Scott Inlet, and c) Qaqulluit National Wildlife Area.

counts) and collectively represented the complete breeding area for each site. Resultant stitched images ranged from $600 \times 600$ dpi to $900 \times 900 \mathrm{dpi}$, with total sizes $60-100$ megapixels each. With each large image, we zoomed into parts of the file (typically 200-300 $\times$ magnification), placed a coloured dot over each identified fulmar, counted the entire image, and then tallied up total birds observed at each site. Repeatability of counts from portions of colonies varied, largely due to some differences in the quality of the images, but was generally high. For example, at Scott Inlet, two separate counts of the same five images (total count mean $=9050$ fulmars) by the same observer had a difference of $0.2 \%$ (16 birds). For interobserver comparisons from Buchan Gulf and Qaqulluit, four subsamples from images conducted among three observers

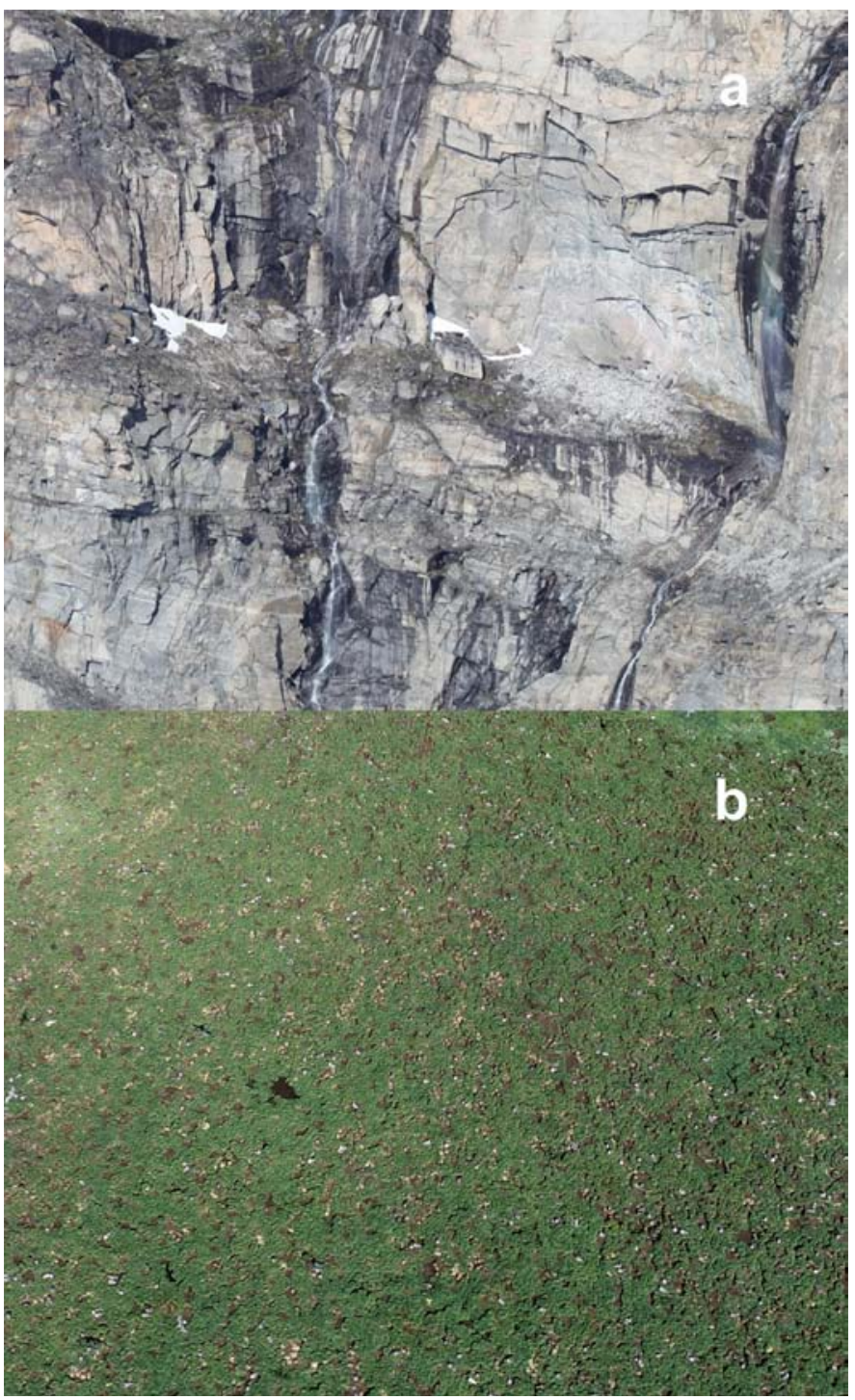

FIG. 3. Representative portions of photos from Northern Fulmar census work at Qaqulluit National Wildlife Area: a) cliffs, and b) top of the rock towers.

yielded an average difference in mean counts of $6 \%$. We did not correct counts for individual differences, and we used maximum counts per colony.

Following counts of birds, we corrected for standardized reporting of fulmar colony size, which includes adjustments for the timing of census as well as breeding and nonbreeding birds. Fulmar attendance at colonies varies through the season, with peak attendance near early July and then declining through August. Counts at Buchan Gulf and Scott Inlet were conducted at peak attendance and thus no corrections were required. However, counts at Qaqulluit were much later; thus, we corrected counts by dividing the total number of individuals by 0.64 , the approximate correction factor to peak attendance for a count taken on 11 August (Gaston et al., 2006: Fig. 4), so that our estimates were consistent with other fulmar colonies in Nunavut. Gaston et al. (2006) also demonstrated that counts should be corrected to "apparently occupied sites" (AOS) because some fulmars at the sites are loafing birds, 
TABLE 1. Northern Fulmar (Fulmarus glacialis) breeding colony locations in northern Canada and their estimated sizes (breeding pairs) since the 1970 s.

\begin{tabular}{lccrll}
\hline \hline Colony & Latitude $\left({ }^{\circ} \mathrm{N}\right)$ & Longitude $\left({ }^{\circ} \mathrm{W}\right)$ & Colony size (pairs) & Year & Reference \\
\hline Buchan Gulf & \multirow{2}{*}{71.83} & 74.5 & 25000 & 1973 & Brown et al., 1975; Hatch and Nettleship, 1998 \\
& & & 5000 & 2018 & $\begin{array}{l}\text { This study } \\
\text { Scott Inlet }\end{array}$ \\
& 71.05 & 71.13 & $25000-30000$ & 1973 & Brown et al., 1975; Gaston et al., 2012 \\
& & & 10000 & 1986 & Hatch and Nettleship, 1998 \\
Cape Searle (Qaqulluit) & \multirow{2}{*}{67.23} & 62.47 & 6000 & 2018 & This study \\
& & & 100000 & 1973 & Brown et al., 1975; Hatch and Nettleship, 1998 \\
& & 35000 & 2001 & Gaston et al., 2006 \\
& & 25500 & 2018 & This study \\
\hline \hline
\end{tabular}

and some sites have two birds at one nest. However, AOS varies among colonies and is determined from dedicated observations of birds on plots and ledges for multiple days (Gaston et al., 2006). In 2018, our methodology only allowed for a quick photographic survey from a brief trip to the colony, so we could not calculate AOS (and it is not known for these sites). Moreover, many of our photos were not of sufficient resolution to distinguish among birds that were nesting, loafing, or paired at a nest site, so we had to count individuals from the photos. Finally, there is no documentation on how most of the earlier colony size estimates for these sites were generated (Gaston et al., 2006), but they were clearly coarse; apparently total individuals were counted and then divided by two to calculate breeding pairs (see also Gaston et al., 2006, 2012). For these reasons, we decided to report estimated breeding pairs at the colony. From one fulmar monitoring study reported in Gaston et al. (2006), breeding pairs were calculated as 0.66 of total individuals, so here we report a range of estimated breeding pairs, calculated as 0.5 times the total count, up to 0.66 times our seasonally corrected counts of birds.

\section{RESULTS}

We found Northern Fulmars breeding at each of the sites visited and known from previous counts. At Buchan Gulf, birds were patchily distributed across the cliff face. Many sections that looked suitable for birds had none. For the overall colony count, we tallied 7448 individual fulmars. At Scott Inlet, fulmars were also patchily distributed, but collectively we counted 9056 fulmars, although we note that this could be a slight overestimate, as small patches of snow (still around at that time) and some pale rocks could have been identified as birds given the bright conditions and the resolution of the images.

At Qaqulluit, the images were taken with the sun behind the drone, and the surfaces of the towers were covered in lush green vegetation (Fig. 2). Consequently, both gray and white fulmars were well illuminated and stood out against the surrounding dark surfaces. However, there were sections where vegetation tussocks appeared to be quite tall, creating dark shadows, and in some cases on the images, we could see fulmars in those shadowy sections, but in others we could not detect birds. Also, on the tower tops, the nesting fulmars had a much more uniform distribution than at the other colonies (or previously found on the cliffs of Cape Searle), but apparent nesting densities were higher on the outer, eastern tower than the inner, western tower. We counted 9463 fulmars on the outer tower top and 5990 fulmars on the inner tower top.

Following the raw counts, conversion to breeding pairs (count $\times 0.5-0.66)$ meant we estimated approximately $3724-4916(\sim 3700-5000)$ breeding pairs of fulmars at Buchan Gulf and 4528-5977 ( 4500-6000) pairs of fulmars at Scott Inlet, both counted near peak colony attendance. For Qaqulluit, 15453 fulmars were counted on the tower tops, and correcting for seasonal declines in birds (Gaston et al., 2006), the cliff tops probably supported 24145 fulmars during peak attendance in early July (i.e., 11 August count/0.64), which would be an estimated $\sim 12072-15936$ breeding pairs.

The cliffs of Qaqulluit supported an estimated 12000 AOS in 2001 near the peak attendance (nests were counted through a spotting scope, with the count then extrapolated to total numbers and converted to 9600 pairs; Gaston et al., 2006). Therefore, we used the older cliff estimate $(9600$ pairs) with the new tower top estimate (above) to suggest that the entire colony currently supports approximately $21672-25536$ breeding pairs.

\section{DISCUSSION}

Consistent with our expectation of overall reduced populations based on anecdotal information from communities and researchers, fulmar numbers at Buchan Gulf and Scott Inlet were markedly lower than published previously (Table 1). A recount of the 1973 photos from Scott Inlet estimated 30000 pairs at that colony (Gaston et al., 2012), which was reduced to 10000 pairs in 1986 (Mallory et al., 2012). We estimated up to 6000 in 2018, which represents a decline of $80 \%$ or $3.5 \%$ year. At Buchan Gulf, the colony once held 25000 pairs, but our counts of up to 5000 fulmar pairs represent a possible decline of 3.5\%/year since 1973 .

Estimating the magnitude of change at Qaqulluit is more difficult because the earlier colony estimates are less reliable. In 1950, Wynne-Edwards (1952) estimated that this 
colony supported 200000 individual birds (often reported as $\sim 100000$ pairs), although he expressed substantial caution on this number. In 1953, Watson (1957) suggested only 25000 individual fulmars were at the Qaqulluit colony, but his surveys were conducted in late May, at a time when the fulmar exodus would have been underway and up to $90 \%$ of the birds could have departed the colony prior to returning for egg-laying (Mallory and Forbes, 2007). Thus, conceivably the estimate of 200000 birds in the 1950s may have been realistic. Twenty years later in 1973, this estimate of 200000 birds was again suggested following aerial surveys (Hatch and Nettleship, 1998). However, Mallory surveyed the colony in 2001-02 (Mallory et al., 2006) and initially estimated $40000-60000$ pairs at the colony, but this estimate was later reduced to 35000 breeding pairs after applying standardized approaches (Gaston et al., 2006). Our new estimate suggests 25500 breeding pairs at peak attendance, approximately $75 \%$ lower than in 1973, and thus a decline of approximately 3\%/year, slightly less steep than the other colonies. For all historical counts except the 1973 aerial survey, observers attempted to estimate colony size at Qaqulluit without being able to see most the birds on the top of the inner and outer towers, where densities are highest (Watson, 1957; Gaston et al., 2006). Irrespective of the accuracy of earlier counts, both qualitative and quantitative assessments suggest that there are now far fewer birds than there were several decades ago.

Indeed, our results are consistent with a general pattern of decline in Northern Fulmars across the North Atlantic. After decades of an expanding population (Mitchell et al., 2004), data from many North Atlantic regions indicate either a stabilization or decline in numbers of breeding fulmars starting around the end of the 20th century (Mitchell et al., 2004; Garðarsson et al., 2011; Mallory et al., 2012; Fauchald et al., 2015). Although some differences in counts are attributed to census methodology, lower adult survival due to climate change (Grosbois and Thompson, 2005 ) and negative interactions with fisheries (Tasker et al., 2000; Løkkeborg, 2011; Hedd et al., 2016) are likely contributing to the trend. Gaston et al. (2006) also reviewed suggestions that some former, small fulmar colonies around Cumberland Sound in eastern Baffin Island had disappeared following the end of whaling in this region. Conceivably, fulmars could have exploited whaling activity along eastern Baffin Island in the past, allowing colonies to build, and then with the cessation of local whaling (and associated scavenging opportunities for birds), colonies could have been in slow decline for some time.

Our revision to the size of three fulmar colonies along eastern Baffin Island adjusts the Canadian Arctic population estimate for fulmars substantially (and consequently the Canadian population because almost all Canadian fulmars nest in the Arctic; Mallory, 2006). Gaston et al. (2012) suggested that there were 174000 pairs of fulmars in the Canadian Arctic based on data available up to 2012 for all colonies in Nunavut. If we assume the estimated number of fulmars at other colonies is the same, but our new census work shows fewer birds at these three colonies, the estimate is reduced to 137500 breeding pairs in the Canadian Arctic. This decline follows the pattern identified by Gaston et al. (2012) where most fulmar colonies that had been recently censused were smaller than the previous breeding population estimates, although the authors were unsure if this represented actual declines or differences in methodology. Qaqulluit (Cape Searle) is likely still the largest Canadian colony, but the reductions in colony sizes of fulmar colonies on eastern Baffin Island may mean that a higher proportion of Canada's fulmars breed in the high Arctic around Lancaster Sound than previously considered.

The decline in the number of fulmars breeding on eastern Baffin Island is likely not attributable to a single factor. Fulmar populations face many stressors related to climate change leading to changes in food webs (Thompson and Ollason, 2001; Grosbois and Thompson, 2005), competition with or mortality from fisheries (Tasker et al., 2000), increasing levels of plastic pollution to which they are highly susceptible (Provencher et al., 2017), and chemical contamination of food webs (Braune et al., 2010, 2011; Helgason et al., 2010). Increasing commercial fisheries activity in Baffin Bay could lead to locally greater bycatch of fulmars (Anderson et al., 2018), exacerbating the declining trend of these colonies. A rate of decline of $\sim 3 \% / \mathrm{yr}$ corresponds to an $87 \%$ decline over three generations (66 years; Anderson et al., 2018), an alarming rate for population viability in long-lived species (IUCN, 2000).

Monitoring fulmar colonies in the Canadian Arctic is exceptionally challenging for a variety of logistical reasons (e.g., Mallory et al., 2018). While preferred protocols for colony monitoring have been detailed (Gaston et al., 2006), the reality is that opportunities like we report here from 2018 may be our only way to try to index numbers of birds at some of these sites. Nonetheless, even with our coarse approaches and estimates, the consistent spatial and temporal pattern is one of decline, perhaps at alarming rates. Based on our recent findings we make three recommendations regarding future fulmar work in this region: 1) surveys, either with an established camp or with a brief photographic inventory, need to be conducted at Akpait National Wildlife Area and at Exeter Island, two colonies within $\sim 120 \mathrm{~km}$ of Qaqulluit that purportedly support 30000 pairs of fulmars, to ascertain if their numbers are also lower; 2) new surveys of the colonies in Lancaster Sound should be conducted to determine if similar declines have occurred in that region; and 3) measures should be taken in the growing Arctic fisheries to minimize fulmar bycatch and thus additional population declines from these east Baffin Island colonies.

\section{ACKNOWLEDGEMENTS}

We thank hunters from the community of Qikiqtarjuaq for essential field assistance, and the Nattivak Hunters' and Trappers' 
Organization for coordinating field activities, especially Alison Kopalie for the logistical support. We also thank the community members that helped with this work; Jaypootee Aliqatuqtuq, Harry Alookie, Stevie Aulaqiaq, Jaloo Kooneeliusie, Jonathan Aliqatuqtuq, John Alookie, Jeanie Toomasie, and Peter Kooneeliusie. Allan Milton from Pond Inlet assisted with helicopter surveys. Thanks also to Michel Gendron, Ryan Franckowiak, and Uluriak Amarualik for their assistance with the surveys. Financial and logistic support were provided by Environment and Climate Change Canada, Natural Resources Canada (Polar Continental Shelf Program), Indigenous and Northern Affairs Canada (Northern Contaminants Program), and Acadia University. Tony Gaston provided comments and guidance with some aspects of the work, and we thank two referees who provided valuable comments on the manuscript.

\section{REFERENCES}

Anderson, C.M., Iverson, S.A., Black, A., Mallory, M.L., Hedd, A., Merkel, F., and Provencher, J.F. 2018. Modelling demographic impacts of a growing Arctic fishery on a seabird population in Canada and Greenland. Marine Environmental Research 142:80-90.

https://doi.org/10.1016/j.marenvres.2018.09.021

BirdLife International. 2019. Species factsheet: Northern Fulmar Fulmarus glacialis.

http://datazone.birdlife.org/species/factsheet/northern-fulmarfulmarus-glacialis

Braune, B.M., Mallory, M.L., Butt, C.M., Mabury, S.A., and Muir, D.C. 2010. Persistent halogenated organic contaminants and mercury in Northern Fulmars (Fulmarus glacialis) from the Canadian Arctic. Environmental Pollution 158(12):3513-3519. https://doi.org/10.1016/j.envpol.2010.08.023

Braune, B.M., Trudeau, S., Jeffrey, D.A., and Mallory, M.L. 2011. Biomarker responses associated with halogenated organic contaminants in Northern Fulmars (Fulmarus glacialis) breeding in the Canadian Arctic. Environmental Pollution 159(10):2891 - 2898 . https://doi.org/10.1016/j.envpol.2011.04.036

Brown, R.G.B., Nettleship, D.N., Germain, P., Tull, C.E., and Davis, T. 1975. Atlas of eastern Canadian seabirds. Ottawa: Canadian Wildlife Service.

Environment Canada. 2005. Guidelines for visiting seabird colonies in the Canadian Arctic. Yellowknife: Canadian Wildlife Service.

Fauchald, P., Anker-Nilssen, T., Barrett, R.T., Bustnes, J.O., Bårdsen, B.-J., Christensen-Dalsgaard, S., Descamps, S., et al. 2015. The status and trends of seabirds breeding in Norway and Svalbard. NINA Report 1151, Tromsø, Norway: Norwegian Institute for Nature Research. 84 p.

Frederiksen, M., Mavor, R.A., and Wanless, S. 2007. Seabirds as environmental indicators: The advantages of combining data sets. Marine Ecology Progress Series 352:205-211. https://doi.org/10.3354/meps07071
Garðarsson, A., Guðmundsson, G.A., and Lilliendahl, K. 2011. Fýlabyggðir fyrr og nú [Fulmar colonies past and present]. Bliki 31:1-10.

Gaston, A.J. 2003. Synchronous fluctuations of Thick-billed Murre (Uria lomvia) colonies in the eastern Canadian Arctic suggest population regulation in winter. The Auk 120(2):362-370. https://doi.org/10.1093/auk/120.2.362

Gaston, A.J., Gilchrist, H.G., and Mallory, M.L. 2005. Variation in ice conditions has strong effects on the breeding of marine birds at Prince Leopold Island, Nunavut. Ecography 28(3):331 - 344. https://doi.org/10.1111/j.0906-7590.2005.04179.x

Gaston, A.J., Mallory, M.L., Gilchrist, H.G., and O’Donovan, K. 2006. Status, trends and attendance patterns of the Northern Fulmar Fulmarus glacialis in Nunavut, Canada. Arctic 59(2):165- 178 .

https://doi.org/10.14430/arctic339

Gaston, A.J., Bertram, D.F., Boyne, A.W., Chardine, J.W., Davoren, G., Diamond, A.W., Hedd, A., et al. 2009. Changes in Canadian seabird populations and ecology since 1970 in relation to changes in oceanography and food webs. Environmental Reviews 17:267-286. https://doi.org/10.1139/A09-013

Gaston, A.J., Mallory, M.L., and Gilchrist, H.G. 2012. Populations and trends of Canadian Arctic seabirds. Polar Biology $35: 1221-1232$.

https://doi.org/10.1007/s00300-012-1168-5

Grosbois, V., and Thompson, P.M. 2005. North Atlantic climate variation influences survival in adult fulmars. Oikos 109(2):273-290. https://doi.org/10.1111/j.0030-1299.2005.13774.x

Hatch, S.A., and Nettleship, D.N. 1998. Northern fulmar (Fulmarus glacialis). In: Poole, A., and Gill, F., eds. The birds of North America, No. 361. Philadelphia. Pennsylvania: The Birds of North America, Inc.

Hedd, A., Regular, P.M., Wilhelm, S.I., Rail, J.-F., Drolet, B., Fowler, M., Pekarik, C., and Robertson, G.J. 2016. Characterization of seabird bycatch in eastern Canadian waters, 1998-2011, assessed from onboard fisheries observer data. Aquatic Conservation: Marine and Freshwater Ecosystems 26(3):530-548.

https://doi.org/10.1002/aqc.2551

Helgason, L.B., Verreault, J., Braune, B.M., Borgå, K., Primicerio, R., Jenssen, B.M., and Gabrielsen, G.W. 2010. Relationship between persistent halogenated organic contaminants and TCDD-toxic equivalents on EROD activity and retinoid and thyroid hormone status in Northern Fulmars. Science of the Total Environment 408(24):6117-6123. https://10.1016/j.scitotenv.2010.08.037

IUCN (International Union for Conservation of Nature). 2020. IUCN red list of threatened species. https://www.iucnredlist.org

Løkkeborg, S. 2011. Best practices to mitigate seabird bycatch in longline, trawl and gillnet fisheries-efficiency and practical applicability. Marine Ecology Progress Series 435:285-303. https://doi.org/10.3354/meps09227 
Mallory, M.L. 2006. The Northern Fulmar (Fulmarus glacialis) in Arctic Canada: Ecology, threats, and what it tells us about marine environmental conditions. Environmental Reviews 14(3):187-216. https://doi.org/10.1139/a06-003

Mallory, M.L., and Braune, B.M. 2012. Tracking contaminants in seabirds of Arctic Canada: Temporal and spatial insights. Marine Pollution Bulletin 64(7):1475-1484. https://doi.org/10.1016/j.marpolbul.2012.05.012

Mallory, M.L., and Forbes, M.R. 2007. Does sea ice constrain the breeding schedules of High Arctic Northern Fulmars? The Condor 109(4):894-906. https://doi.org/10.1650/0010-5422(2007)109[894:DSICTB]2.0. $\mathrm{CO} ; 2$

Mallory, M.L., and Gaston, A.J. 2005. Monitoring northern fulmars in the Canadian Arctic: Plot locations and counts at selected colonies. Technical Report No. 432. Ottawa: Canadian Wildlife Service. 58 p.

Mallory, M.L., Fontaine, A.J., Akearok, J.A., and Johnston, V.H. 2006. Synergy of local ecological knowledge, community involvement and scientific study to develop marine wildlife areas in eastern Arctic Canada. Polar Record 42(3):205-216. https://doi.org/10.1017/S0032247406005481

Mallory, M.L., Hatch, S.A., and Nettleship, D.N. 2012. Northern fulmar (Fulmarus glacialis). In: Poole, A., ed. The birds of North America online, No. 361. Ithaca: Cornell Lab of Ornithology. https://doi.org/10.2173/bna.361

Mallory, M.L., Gilchrist, H.G., Janssen, M., Major, H.L., Merkel, F., Provencher, J.F., and Strøm, H. 2018. Financial costs of conducting science in the Arctic: Examples from seabird research. Arctic Science 4(4):624-633. https://doi.org/10.1139/as-2017-0019

Mallory, M.L., Gaston, A.J., Provencher, J.F., Wong, S.N.P., Anderson, C.A., Elliott, K.H., Gilchrist, H.G., et al. 2019. Identifying key marine habitat sites for seabirds and sea ducks in the Canadian Arctic. Environmental Reviews 27(2):215-240.

https://doi.org/10.1139/er-2018-0067
Mitchell, P.I., Newton, S.F., Ratcliffe, N., and Dunn, T.E. 2004. Seabird populations of Britain and Ireland: Results of the seabird 2000 census (1998-2002). London: T. \& A.D. Poyser.

Paleczny, M., Hammill, E., Karpouzi, V., and Pauly, D. 2015. Population trend of the world's monitored seabirds, 1950-2010. PLoS ONE 10(6): e0129342. https://doi.org/10.1371/journal.pone.0129342

Piatt, J.F., Sydeman, W.J., and Wiese, F. 2007. Introduction: A modern role for seabirds as indicators. Marine Ecology Progress Series 352:199-204. https://doi.org/10.3354/meps07070

Provencher, J.F., Bond, A.L., Avery-Gomm, S., Borrelle, S.B., Bravo Rebolledo, E.L., Hammer, S., Kühn, S., et al. 2017. Quantifying ingested debris in marine megafauna: A review and recommendations for standardization. Analytical Methods 9:1454- 1469 . https://doi.org/10.1039/c6ay02419j

Sydeman, W.J., Thompson, S.A., Piatt, J.F., García-Reyes, M., Zador, S., Williams, J.C., Romano, M., and Renner, H.M. 2017. Regionalizing indicators for marine ecosystems: Bering Sea-Aleutian Island seabirds, climate, and competitors. Ecological Indicators 78:458-469. https://doi.org/10.1016/j.ecolind.2017.03.013

Tasker, M.L., Camphuysen, C.J., Cooper, J., Garthe, S., Montevecchi, W.A., and Blaber, S.J. 2000. The impacts of fishing on marine birds. ICES Journal of Marine Science 57(3):531-547. https://doi.org/10.1006/jmsc.2000.0714

Thompson, P.M., and Ollason, J.C. 2001. Lagged effects of ocean climate change on fulmar population dynamics. Nature 413:417-420. https://doi.org/10.1038/35096558

Watson, A. 1957. Birds in Cumberland Peninsula, Baffin Island. Canadian Field-Naturalist 71:87-109.

Wong, S.N.P., Gjerdrum, C., Gilchrist, H.G., and Mallory, M.L. 2018. Seasonal vessel activity risk to seabirds in waters off Baffin Island, Canada. Ocean \& Coastal Management 163:339-351.

https://doi.org/10.1016/j.ocecoaman.2018.07.004

Wynne-Edwards, V.C. 1952. The fulmars of Cape Searle. Arctic 5(2):105- 117 .

https://doi.org/10.14430/arctic3902 